\title{
Norway and Turkey: Possibilities of Cooperation through the Eyes of Turkish Opinion-Makers
}

\author{
Daniel Heradstveit and Siri Neset \\ Norwegian Institute of International Affairs \\ G. Matthew Bonham \\ Syracuse University
}

\begin{abstract}
The authors conducted interviews with opinion-makers in Turkey in 2012 to explore the feasibility of cooperation between Turkey and Norway on issues of peacebuilding. Norway was viewed by respondents as a country with softpower capabilities and a focus on human rights, democratic values, and the rule of law. Some opinion-makers also emphasized that both countries have a similar position on Palestine, a pivotal issue in the Middle East. Obstacles to cooperation include the geographical distance between the two countries, the lack of common institutions, Norway's lack of experience with different ethnicities and faiths, Norway's failure to object to the 2005-2006 Danish cartoon scandal regarding Mohammed, Norwegian criticism of Turkey's policies toward the Kurds, and its imprisonment of dissidents without due process of law. Despite these issues, respondents expressed enthusiasm about future cooperation, and view Norway as a far better potential collaborator than any other European country, in part because it, like Turkey, is outside the EU but a member of NATO. The issue of trade-offs between Norway's use of soft power and its economic aspirations, namely oil investments in other countries, was also explored. The article concludes with a discussion of the possibility that increased cooperation between Turkey and Norway may give rise to "Turkophobia", an extension of "Islamophobia", a simplistic interpretative framework that rests on cultural misunderstanding and miscommunication.
\end{abstract}

Keywords: Turkish-Norwegian cooperation, peacebuilding, democracy, soft power, tradeoffs, Turkophobia

\section{Introduction}

Turkey's dynamic and unprecedented economic development in recent years, followed by a number of domestic and international peacemaking initiatives has sparked Norwegian interest in closer ties with Turkey. Inspired by this development, the authors of this article investigated whether there is potential for closer cooperation between Norway and Turkey on peace efforts and democracy promotion in the wake of the Arab Spring. ${ }^{1}$

The Arab Spring has challenged beliefs about the incompatibility between Islam and

Daniel Heradstveit, Professor Emeritus, Norwegian Institute of International Affairs. E-mail: daniel.heradstveit@nupi.no. Siri Neset, Research Fellow, Norwegian Institute of International Affairs. E-mail: sne@nupi.no. G. Matthew Bonham, G. Matthew Bonham. Professor, International Relations and Political Science, Syracuse University. E-mail: gmbonham@maxwell.syr.edu.

1 This ongoing research was initiated by Daniel Heradstveit and Siri Neset and received funding from the Norwegian Ministry of Foreign Affairs and the Norwegian Peacebuilding Resource Center. 
democracy. Many in the Arab world have pointed to Turkey as an example of how to create a democratic regime in an Islamic country: the Turkish Model. ${ }^{2}$

With the rise of Turkey's Justice and Development Party (Adalet ve Kalkinma Partisi; AKP), the Turkish Model exemplifies that a party with roots in political Islam can evolve into a democratic party of government. ${ }^{3}$ The AKP has further demonstrated capabilities to resolve the leading challenge to the Muslim world today, namely, the management and political integration of Islam. ${ }^{4}$ Some voices in Turkey, however, both within the AKP and the opposition, do not echo the view that the present government lives up to the Turkish Model. The opposition has complained that Prime Minister Recep Tayyip Erdogan has not applied at home the democratic recommendations he has advocated abroad. ${ }^{5}$

The research community studying the Turkish Model also reaches a mixed verdict. Manal Lofti, for example, highlights the fact that Turkey is shaped by its particular history and therefore cannot be a model for other countries in the region-in other words, the Turkish Model is not replicable. ${ }^{6}$ Emad Kaddorah agrees with this view, saying that instead of imitating the Turkish Model, neighboring states should initiate their own positive models because each state has its own attributes and features. ${ }^{7}$

Under the present government, the Turkish Model is increasingly referred to as the "Turkish inspiration". Tarık Oğuzlu claims that Turkey can only inspire Muslim countries in the region, for example, regarding preserving secular and democratic governments in a society where the majority of people are Muslims, or strengthening the idea that legitimate leadership only becomes a possibility by winning freely held elections. ${ }^{8}$ Likewise, Nora Fisher Onar calls the Turkish Model "a model-in-progress", but states it cannot be contested that this model has shown that the combination of Islam, democracy, and secularism works. ${ }^{9}$ These components of the Turkish model are evidence that our standard view of Islam needs to be revised. Onar also argues that this model-in-progress continues to offer a timely example for the region. ${ }^{10}$

Sinan Ülgen identifies five characteristics of the Turkish Model:

(1) Secularism, Democracy, and Political Islam: The Turkish political system has been able to accommodate political Islam, the principle of secularism as well as democracy. (2) Civil-Military Relations: the Turkish military has played a major role as the watchdog for republican principles in the country. (3) Market-State Relations: The Turkish Model is characterized by economic liberalization and trade integration, which have led to the development of a business class independent of the government. (4) Links to the West: Since the founding of the Turkish republic, Turkish leaders have anchored Turkey in the West,

\footnotetext{
2 Marwan Muasher et al., "Can the Turkish Model Gain Traction in the New Middle East?" Carnegie Endowment for International Peace, December 19, 2011, accessed November 2, 2012, http://carnegieendowment.org/2011/12/19/can-turkish-modelgain-traction-in-new-middle-east.

“Turkish Model has shortcomings," Oxford Analytica, February 21, 2011, accessed February 5, 2013, http://www.relooney. info/0_NS4053_1608.pdf.

- Graham E. Fuller, “Turkey's Strategic Model: Myths and Realities,” The Washington Quarterly 27 (2004): 51-64.

"Turkish Model has shortcomings."

"Turkey from Ataturk to Erdogan," Asharq al-Awsat, November 9, 2007, accessed February 9, 2013, http://www.aawsat. net/2007/11/article55260861.

Emad Kaddorah, "The Turkish Model: Acceptability and Apprehension," Insight Turkey 12 (2010): 113-129.

8 Tarı Oğuzlu, "Is the 'Turkey As a Model' Idea Turning into Reality from Perception?" ORSAM, December 5, 2011, accessed February 11, 2013, http://www.orsam.org.tr/en/showArticle.aspx?ID=951.

9 Nora Fisher Onar, "Turkey Inc.: Rethinking the Model's Regional Role," Carnegie Endowment for International Peace, March 29, 2012, accessed February 10, 2013, http://carnegieendowment.org/sada/2012/03/29/turkey-inc.-rethinking-turkey-sregional-role $/ \mathrm{a} 5 \mathrm{k} 9$.

${ }^{10}$ We may add that it is also an example for the West.
} 
seeking memberships in Western, multilateral organizations like NATO. (5) State Traditions: Turkey has a long history of bureaucratic traditions carried over from the Ottoman Empire, which has led to popular confidence in the countries [sic] institutions. ${ }^{11}$

The Arab Spring has opened up a new window of opportunity for Turkey's policies on peace and democracy in the region. Today, aware of its increasing potential for influence, Turkey states that it pursues a multi-dimensional foreign policy that is pre-emptive rather than reactive. Security for all, political dialogue, economic interdependence, and cultural harmony are the building blocks of Turkey's vision for the New Middle East. ${ }^{12}$

Norway has good potential to be an active third party in promoting democratic thinking in the wake of the Arab Spring. Turkey and Norway are both members of NATO and both outside the EU. The two countries are well positioned to collaborate to improve and stabilize democratic systems, reinforce civil society, and initiate interfaith dialogue. They could also collaborate to develop mediation and peacebuilding expertise and capacities..$^{13}$

\section{Our Approach}

To learn more about the possibilities for collaboration between Turkey and Norway, we conducted interviews in 2012 with elite opinion-makers in Turkey. Our goal was to understand how Turkey might view Norway as a partner for promoting democracy and initiating peace efforts in the Arab Middle East. Our underlying assumption is that positive interaction would follow from such cooperation.

Elite interviewing is a potent source of data-collection for political scientists doing empirical research. There are many approaches to such interviewing, and we decided to conduct in-depth interviews with open-ended questions to allow us to discuss at length respondents' thoughts on key issues relevant to the research topic. ${ }^{14}$ This format also allowed respondents to talk freely without the constraints of having to answer questions according to fixed categories.

Although the interview instrument was open-ended, the questions were standardized. We followed the advice of Philip E. Converse to use the original item introduced when asking the question a second time, regardless of measurement error, instead of having to compare results from different question wordings. ${ }^{15}$

In social science there is no consensual definition of "elite," so the statistical population cannot be defined, which means it is not possible to construct a representative sample in a statistical sense. ${ }^{16}$ Thus, after consulting with experts on Turkey we drew up a list of persons qualified for interviewing. Further, having obtained an interview, we asked the respondent

\footnotetext{
11 Muasher et al., "Can the Turkish Model?"

12 "Policy of Zero Problems with our Neighbors," Republic of Turkey, Ministry of Foreign Affairs, accessed November 10, 2012, http://www.mfa.gov.tr/policy-of-zero-problems-with-our-neighbors.en.mfa.

13 The Norwegian Ministry of Foreign Affairs signed an agreement in January 2012 to promote cooperation between research groups working in Middle Eastern countries. "Press Release," The office of the Prime Minister, accessed November 6, 2012, http:// www.regjeringen.no/en/dep/smk/press-center/Press-releases/2012/increased-cooperation-between-norway-and.html?id=668571.

14 For recent discussions on similar approaches, see Oisin Tansey, "Process Tracing and Elite Interviewing: a Case for Nonprobability Sampling," Political Science and Politics 40 (2007): 765-772; Jeffery M. Berry (2002), "Validity and Reliability Issues in Elite Interviewing," Political Science and Politics 35 (2002): 679-682; and Alexander L. George and Andrew Bennett, Case Studies and Theory Development in the Social Sciences. (Cambridge: MIT Press, 2005).

15 Cited in Joel D. Aberbach and Bert A. Rockman, "Conducting and Coding Elite Interviews," Political Science and Politics 35 (2002): 675 .

16 Daniel Heradstveit, Arab-Israeli Conflict: Psychological Obstacles to Peace (Oslo: Universitetsforlaget, 1979; New York: Columbia University Press, 1981): 40.
} 
to name other possible interviewees. ${ }^{17}$ This technique is known as chain sampling. A clear disadvantage of chain sampling is that the respondents may choose persons of their own liking, and so we deemed it important to combine the two methods. The interviews were carried out in Istanbul and Ankara in March and April 2012 with well-informed Turkish elite from academia, politics, journalism and think tanks. ${ }^{18}$

Our methodology involved time-consuming subsequent response coding. Although we asked interviewees to discuss eight issues, we explore only three in this article: the image of Norway, the relationship between Turkey and Norway, and the possibilities for more cooperation between Norway and Turkey on issues of peacebuilding after the Arab Spring. ${ }^{19}$ To code the interviews, we created two main categories and four sub-categories. We called the first main category "The image of Norway", and its subcategories "Wonderful Norway" and "The problematic side of Norway." We called the second main category "Cooperation between Norway and Turkey", and its subcategories "Issues that promote cooperation" and "Obstacles to future cooperation".

In analyzing the data we relied on the hermeneutical approach. Maurizio Ferraris defines hermeneutics as "the art of interpretation as transformation," and he contrasts it with a view of theory as "contemplation of eternal essences unalterable by their observer". ${ }^{20}$ Hans Georg Gadamer describes hermeneutics "as the skill to let things speak which come to us in a fixed, petrified form, that of the text". ${ }^{21}$

The starting point for our analysis is the potential for extended cooperation between Norway and Turkey around democracy promotion, interfaith dialogue and peacebuilding. In reading the texts it became clear to us that some topics merited closer attention. The first was Norway's positive international image and its potential for a "spillover" effect to Turkey. The second was whether proposed trade-offs in Norwegian foreign policy with regard to oil exploration might interfere with its soft power approach. Third, concern was expressed regarding the potential for Turkophobia in Norwegian society, especially in the aftermath of right-wing extremist Anders Behring Breivik's attacks in Oslo and at Utøya on July 22, 2011.

\section{The Turkish Image of Norway}

In this article we concentrate on results directly related to Turkish-Norwegian cooperation, beginning with the Turkish image of Norway and its role in the world. ${ }^{22}$

When asked about their perceptions of Norway, respondents most frequently mentioned Norway's soft-power capabilities, followed by norm-related issues. According to one of our respondents, Norway is "the one and only" on soft power. Norway's focus on human factors, human rights, democratic values, and the rule of law were noted as examples of Norway's norm-setting power: "Norway has the ability to both inspire and challenge other countries normatively”. Respondents also stressed Norway's high standard of living, wealth, freedom, and equality as factors that contribute to its soft power capabilities.

17 We interviewed 12 people from Istanbul and Ankara in this exploratory study.

18 The opinion-makers signed a consent form after being informed of the potential risks involved.

19 The other issues discussed were: the "tug of war" between secularism and Islamism in Turkey; the state of democracy in Turkey; perceptions of the Turkish model; the Turkish image of the United States; and the leadership styles of Prime Minister Erdogan and his Foreign Minister Ahmet Davutoğlu.

${ }_{20}$ Maurizio Ferraris, History of Hermeneutics (Atlantic Highlands, NY: Humanities Press, 1996).

21 Hans Georg Gadamer, "Interview: Writing and the Living Voice," in Hans-Georg Gadamer on Education, Poetry and History, eds. Dieter Misgeld and Graeme Nicholson (New York: State University of New York Press, 1992): 63-71.

22 There is, to our knowledge, no previous research on how Turks view Norway and the Norwegians. 
As a small power, Norway is viewed as somewhat limited in how it can operate on the international scene. Further, Turkish opinion-makers emphasized that Norway is not seen as a military power. Nevertheless, Norwegian governments have exploited what their country can do internationally by propagating norms and soft power, and respondents feel that Norway makes its presence known. This perception is definitely influenced by Norway's values in domestic politics and foreign policy. Norway is a well-functioning democracy. Its stubbornness in promoting norms in international relations is well known and it has achieved much in this regard, based on the "general decent image" of Norwegians as "do-gooders" internationally. Norway, furthermore, is known for its active participation in development issues and for its foreign aid policy. Although Norway is a small country, respondents view it as an important one, providing a model for others.

Norway is perceived as a peaceful nation, but some opinion-makers see this to be partly as a consequence of its relatively isolated geography. One respondent noted that Norway is fortunate to have a long coastline, with no neighbors imposing on its territory. Respondents feel that Norway conducts itself in a manner most appropriate to its geographic position and small population (about five million), i.e., emphasizing soft power and human rights over hard power. Norway is in no position to build a large army or navy and acquire weaponry that would make it competitive with larger countries.

One interviewee put forward the idea that Norway might be vulnerable to the dangerous phenomenon of Islamophobia or fascism because of its homogeneous population with the same religious background. ${ }^{23}$ In other words, the country lacks experiences in living together with different ethnicities, as well as different religious faiths. "Norwegians don't know how to live with diversity," the respondent claimed. This is a potential threat to Norway as a country-Breivik's attacks, which killed 77 people, may be an omen of things to come. Islamophobia on a more general level could also be transformed into "Turkophobia."

Turkish opinion-makers also mentioned that Norway's image of a global peacemaker could backfire in the long run because Norway is also perceived as an oil-producing country. At the outset, most of its oil came from the North Sea and therefore presented no foreign policy problems. But today, when Norway also operates in other countries, the Norwegian oil industry may spark issues contradictory to the country's peace and reconciliation efforts.

\section{The Potential for Cooperation between Norway and Turkey}

When it comes to the idea of collaborating with Norway on promoting peacebuilding in the Arab Middle East, we cite the respondent who said, "Obviously... Norway is the best choice for Turkey and Turkey is the best (if not [the] only - who else?) option for Norway." Generally, Norway is considered a far better collaborator than any other European country: "As a matter of fact, we can assure you that this will be a non-controversial issue in Turkey".

Some interviewees admitted that although Norway and Turkey do not have many things in common, the fact that neither Turkey nor Norway is a member of the EU and that they are both members of NATO would be helpful in developing an extended relationship. Turkey's role as an international actor is increasing, but closer cooperation with Norway in the field of peace and reconciliation is potentially of great importance. One opinion-maker phrased it as follows: "Norway's soft power and the Turkish model could be a success-both in the Middle East and Asia."

23 Looking only at population statistics, one may think that Norway is a highly heterogeneous society. There is, however, strong pressure for immigrants to conform to Norwegian culture, resulting in a relatively homogeneous society. 
Other respondents claimed that Norway is practically unknown in Turkey and suggested that Norway should do more to become better known. For example, Norway could do more to attract Turkish tourists, considering its many exotic and interesting features, such as the fjords. Still, it is not easy to create interest for Norway in Turkey, and it is rare that you read something about Norway in the Turkish newspapers.

\subsection{Issues that promote cooperation}

Some respondents emphasized that Norway and Turkey hold the same view of Palestine. This is a good point of departure, because the Palestinian conflict is pivotal to the whole Middle East. The Arab Middle East needs an "honest broker" like Norway, a country that is attached neither to Palestine nor Israel. Turkey, due to recent events, such as the Gaza war and the MV Mavi Marmara incident, has lost credibility as a broker between the Israelis and the Palestinians, and thus Turkey would greatly profit from an alliance with Norway. ${ }^{24}$

Opinion-makers also mentioned that closer cooperation between Norway and Turkey could have a positive effect on democratic values in both countries. From Norway, Turkey could gain deeper insight into a well-functioning democracy, while Norway could gain more knowledge from Turkey about how to live with diversity. One person also stated that Norway could increase the value of the Turkish Model and make it stronger and more credible. Finally, the importance of Norwegian experience and sophistication to Turkey regarding conflict resolution was repeated.

\subsection{Obstacles to future cooperation}

The Turkish elite were reluctant to say anything negative about the idea of cooperation with Norway. They did, of course, say that any dishonesty, ill will, or manipulation on the part of either nation could cause problems. The Turkish opinion-makers stressed the importance of "putting the cards on the table." They also said that Israel could cause problems for this cooperation.

One obstacle to cooperation is that Norway and Turkey are far apart geographically. Another is that the countries lack common institutions. Third, Turkish and Norwegian scholars currently have little interaction, and fourth, the countries' civil societies have few links.

\subsubsection{The Danish cartoons}

When explicitly asked about possible Norway-Turkey cooperation obstacles, the 2005-2006 Danish cartoons that parodied Mohammed and caused a global outcry were mentioned, even though respondents are well aware that the cartoons were published in Denmark. Because of Denmark's geographic proximity to Norway, however, respondents view Denmark as being culturally similar to Norway, and thus that Norway may agree with anti-Islamic sentiments. We were warned that if Norway did something like this, it would clearly have a negative effect on any cooperation with Turkey. Interestingly, there was no mention of religious differences between the two countries, although some people made reference to

24 Only one respondent noted that Norway has been falling out of Israel's good graces since the Oslo Accords. Due to increasing sympathy for the Palestinians by the Norwegian public and the government, Norway is no longer seen as a neutral party or possible mediator by many Israelis. 
Islamophobia, which is said to be widespread in Europe. Linked to this notion was the idea that cultural misunderstanding could cause problems in cooperation between Turkey and Norway.

\subsubsection{Peacebuilding}

Turkish opinion-makers emphasized how advanced Norwegians are in peacebuilding compared to Turkey. "When the Norwegians referred to peacebuilding, the Turks have no clear meaning of what this really means." One respondent noted how this lack of knowledge is reflected in how Turkey deals with the Kurdish problem. A good way for Turkey to begin the peacebuilding process is to move more intelligently on issues with the Kurds.

At the outset of this research effort we thought of two potentially difficult issues in the relationship between Turkey and Norway: Turkey's Kurdish issue and its practice of jailing opponents of the regime without due process. We therefore included these issues in our conversations.

\subsubsection{The Kurds}

Our respondents spoke frankly about the Kurdish issue. They warned Norway that if it supported the PKK, Turkey would "show the red flag" against cooperation. They admitted that government policies were not ideal in the treatment of the Kurds. Historically, the Kurds have been mistreated by the Turkish state; however, this general historical picture must take into account today's Kurdish policy. Interviewees claimed that in the last five years ways of handling the problem have improved, although they admitted that the situation has declined in the last two years.

Respondents expected more sympathy from Norway on the Kurdish issue because of its complexity. It is rarely mentioned, for example, that the issue presents a security problem for Turkey. Respondents feel that the European public and governments lack an understanding of the problem and make superficial criticisms of Turkey without offering constructive solutions.

According to some of our respondents, Turkey is facing potential ethnic divisions that threaten its survival. Turkey experienced such a division during the Ottoman period, when the Empire fell apart. Norway, on the other hand, is a product of rather recent state formation, and has no historical experiences with the disintegration of an empire.

One respondent disagreed with the above statements, finding no fault with the amount of criticism from Norway on the Kurdish issue; greater criticism stems from France, Germany, and Sweden. That respondent felt that the Norwegians are careful not to criticize the Turkish government too much, because the Norwegians are involved in talks between the Kurds and Turkey.

\subsubsection{Jailing without rule of law}

The Turkish opinion-makers argued that when criticizing the state of democracy and problems of minorities in Turkey, people would be better to describe them with some humility, given the difficulties that Turkey must handle simultaneously. On the other hand, it would be wrong for Norwegians not to acknowledge that there are problems with democracy in Turkey. One respondent claimed that Turkey is only halfway down the road to becoming a democratic country. If Norway does not acknowledge the weakness of democratic institutions in Turkey, then Norwegians would lose credibility in Turkey and in the eyes of other countries in the Middle East. 
Turkey's elite were perfectly willing to talk about the country's weaknesses in its democracy. One told us, for example, that a friend gave a lecture at an organization with connections to the PKK. This person was now in jail. It is fair, said our respondent, to criticize human rights breaches in Turkey, and claimed that these problems are increasing.

Interestingly, the government is now jailing a different stratum of society. Previously, minorities were the most vulnerable. Today, minorities have a much better position in Turkish society and are much freer, which is to the credit of the AKP. Now, however, the middle class is most subject to human rights abuses; specifically, journalists, authors, politicians, dissidents, intellectuals and members of the military who oppose the present government's policies.

Some respondents explained that the view of the opposition is that the AKP aims at developing an all-powerful state, in other words, a clearly anti-democratic government. Respondents stated that illegal jailing is now worse than it has ever been. Human rights abuses continue to be standard practices and liberal freedoms are shrinking. In the past, the courts illegally intervened in politics. Today, this situation is reversed, and now it is the government that does not abide by the rule of law and creates obstacles to freedom and the rise of democracy.

Despite criticisms of the Kurdish policy and of jailing dissidents, respondents do not see these as major impediments to closer relations between the two countries. The Turkish elite are enthusiastic about what both countries can stand to gain through such cooperation.

\section{Soft Power, Trade-Offs, and Turkophobia}

In the next section we will discuss three issues of potential importance to the future of Turkish-Norwegian cooperation: soft power, trade-offs, and Turkophobia.

\subsection{Norway's soft-power capacity}

We have already reported that when asked about Norway, respondents most often mentioned its soft power capabilities.

In the academic literature, soft power is defined as a country's ability to obtain its goals in world politics because others admire its values and want to follow its example, i.e., they do not use "hard power" or coercion. ${ }^{25}$ In other words, soft power creates political capital. According to the 2011 global ranking of soft power by the Institute for Government, Norway was ranked eleventh and Turkey twenty-third with respect to soft power. On governance and diplomacy Norway was ranked second and sixth, respectively. ${ }^{26}$

According to Norway's Power and Democracy Report, its soft power approach has been sophisticated since the early 1990s:

\footnotetext{
Norway has been built up as an international brand name, as a particularly peace-loving nation, eager to donate resources and with specific tasks in world politics. The branding takes place through its engagement policy - the work for conflict resolution, peace, democracy, and human rights - around the world. The image of Norway as a moral and humanitarian great power has become a new national symbol in line with other symbols shaping Norwegians' national identity. ${ }^{27}$
}

25 Joseph S. Nye, Soft Power: The Means to Success in World Politics (New York: Public Affairs, 2004).

26 Jonathan McClory, "The New Persuaders II: A 2011 Global Ranking of Soft Power," Institute for Government, 2011, December 1, 2011, accessed December 18, 2012, http://www.instituteforgovernment.org.uk/publications/new-persuaders-ii. 
After the initial success of the Oslo Accords, Norwegian officials recognized that such a method could be further utilized in the international arena. Then-State Secretary Jan Egeland stated: “...our status, in, for example, the Middle East, enables us in other settings to meet on a higher level and in more comprehensive talks. They are interested in our assessment. This way we may get information back that is important to Norway." 28

The so-called Norwegian Model incorporates the idea that a small state may have advantages that ensure impartiality and neutrality, and thus instill confidence in that country as a third party. ${ }^{29}$ The Norwegian Model also emphasizes the usefulness of close cooperation between authorities, NGOs, and academia, as well as a long-term perspective on peacebuilding, including aid and economic support for reconstruction.

After the Oslo Accords, the world community increasingly picked up the concept of the Norwegian Model as a way of proceeding in peacemaking..$^{30}$ By 2002, the Norwegian peace enterprise had grown into a considerable part of Norwegian foreign policy, and the Ministry of Foreign Affairs established the Peace and Reconciliation Unit to coordinate its efforts.

Norway's foreign policy strategy seems to have paid off. When the authors of this article conducted field research in Turkey in the spring of 2012, our respondents confirmed Norway's positive image. They stated that Norwegian governments have genuinely demonstrated what Norway can do on the international scene by propagating norms and soft power as the way forward. Therefore, in spite of its size, Norway achieves its goals.

Today, maximizing Norwegian soft power continues to be a major foreign policy goal. As former Foreign Minister Jonas Gahr Støre states:

\footnotetext{
We have devoted substantial resources to developing a foreign policy strategy where we focus Norwegian efforts and resources towards areas where Norwegian policy can make a difference as well as areas where we can have an impact. We have devoted our attention to issues that are important on their own, but which also present possibilities to develop new norms and to develop new networks with important countries. ${ }^{31}$
}

Recently, realpolitik has been introduced in the discourse of Norwegian foreign policy. Støre elaborates on this concept by stating that Norwegian foreign policy needs direction to best channel the country's economic, political, and human resources: "We have to prioritize to have an impact." According to Støre, two questions guide Norwegian efforts: Is this important to Norwegian interests? and Can Norwegian efforts make a difference? ${ }^{32}$

The bottom line of this policy is the necessity of maintaining Norway's positive image in the world community. Our Turkish respondents feel that cooperation between Turkey and Norway would reflect well on Turkey. "Any government in Turkey ready to collaborate with Norway would strengthen its position," said one. And as another phrased it, "Norway's soft power and the Turkish model could be a success, both in the Middle East and Asia." Norway, in line with its realpolitik, obviously would also be interested in Turkey as a door opener to the Middle East.

\footnotetext{
Reports, NOU 2003: 19. Translation by the authors.

28 "Freds-suksess som 'byttemiddel'," $V G$ (30 January 1995): 22. Cited in Øystein H. Skånland, ”Norway is a Peace Nation: A Discourse Analytic Reading of the Norwegian Peace Engagement," Cooperation and Conflict 45 (2010): $35-54$.

29 That is the advantage of not having a colonial past, a great power's interests, historical or vested interests, nor the muscle to pressure parties.

30 "Norge i fredens tjeneste: Norske bidrag til fred og forsoning," Norwegian Ministry of Foreign Affairs, July 7, 2000, accessed December 26, 2000, http:/www.regjeringen.no/en/dep/ud/documents/Reports-programmes-of-action-and-plans/Reports/2000/ fredenstjeneste.html?id=467585. Translation by the authors.

31 Jonas Gahr Støre, "Utenrikspolitikk i Forandringens tid," Samtiden 4 (2010): 4-19.

32 Støre, "Utenrikspolitikk," 4-19.
} 
Do trade-offs in Norwegian foreign policy interfere with its soft-power approach?

Every country at times must make decisions about trade-offs. In the next section we will discuss to what extent Norwegian policies on soft power are modified by trade-offs in Norwegian foreign policy. Small countries that invest highly in imagery, as discussed above, have more to lose when they make foreign policy decisions that contradict their images.

\subsection{Trade-off problems}

As reported above, one of our opinion-makers expressed the view that Norway could confront a conflict between its economic aspirations and its peacemaking, reconciliation, and development efforts. ${ }^{33}$ Furthermore, not only might it be difficult to combine these aspirations, it might even be counterproductive: peacebuilding efforts might directly obstruct important economic possibilities for Norwegian industry.

Robert Jervis argues that political actors strive to maintain a minimum of important values and therefore will avoid choosing between different equally important values if that means that some values would have to be discarded to promote others. ${ }^{34} \mathrm{~A}$ political actor will especially try to avoid this kind of trade-off if the end game is uncertain and when both (or more) seemingly incompatible values are important. In Norway some foreign policy goals are apparently incompatible, namely, Norway's focus on the international rule of law and multilateral solutions versus its alliance policy and the need for a reliable and solid security foundation within NATO. ${ }^{35}$ Norway must thus make trade-offs, such as it did in the US-led 2003 invasion of Iraq; as we know, Norway chose to refrain from supporting its US ally in the absence of a clear mandate from the UN.

Another area of tension involves Norway's image as a peacemaking country versus its human rights activities. It is often difficult for Norway to consolidate its involvement in peace diplomacy and be heavily engaged in human rights issues. The perceived necessity of pragmatism related to the role of a negotiator collides with the vociferous nature of the activist. In Norwegian foreign policy this discord is most evident in the handling of the Palestinian-Israeli issue.

A third area (noted by only one respondent, however) where Norway may have to engage in trade-offs concerns its interests as a global oil superpower versus its advocacy of human rights in the UN and other forums. In practical terms this means whether or not to speak out against human rights abuses in oil-rich countries if that risks Norwegian companies like Statoil losing major contracts.

Our respondents acknowledged that Norway may be confronted with a difficult question: Should Norway make peace or make money in countries known for their lack of democratic principles, dictatorship, and massive breaches of human rights? Depending how Norway answers that question, it may be in a situation where people's view of the country has shifted from that of a peacemaking champion to a profitmaking champion, from oil extracted from countries with corrupt authoritarian regimes.

Although these trade-offs continue to exist in Norwegian foreign policy, the decisions made in such cases do not appear to have tarnished Norway's image in Turkey. This situation

${ }^{33}$ In this article we only discuss Norwegian trade-offs. We are well aware that Turkey also has trade-off issues that could influence its relationship with Norway, but these will be dealt with at a later stage in our research.

34 Robert Jervis, Perception and Misperception in International Politics, (Princeton: Princeton University Press, 1976).

35 Leiv Lunde et al., Norske Interesser: Utenrikspolitikk for en globalisert verden (Oslo: Cappelen Damm, 2008). 
might be a reflection of Norway's delicate handling of these trade-offs or that the Turkish media rarely mentions Norway.

In the above sections, we discussed issues related to Norwegian foreign policy, but it is also highly relevant to examine the Norwegian domestic landscape, where we are witnessing processes of change with implications for Norway's image in Turkey.

\subsection{Turkophobia}

Turkey is a country between European and Islamic civilizations. The Turkish state is secular, but its population's main religion is Islam. The country is situated in Europe and Asia, and its leaders cooperate with colleagues from neighboring Middle Eastern countries, as well as with colleagues in Europe.

Turkey lies between two categories, Europe and Asia. It has served the Turkish government to underscore this location. This location was earlier reflected in Turkish foreign policy through the "bridge metaphor," which was used to highlight Turkey's geographic position as a bridge between different cultures. Lerna K. Yanik concludes that "the continuous use of [the] 'bridge' metaphor might reinforce Turkey's "liminality," placing Turkey in a less classifiable category than the regular "othering" practices." 36

Turkey cannot be placed firmly in one category or another, and it can be assigned to several, two of them being "Europe" and "Islam." The theory of group processes and categorization states that the process of categorization gives rise to two inevitable consequences: (1) a sharpening of the perceived differences between categories and (2) a leveling of the distinctions within categories. ${ }^{37}$

Which of the two above-mentioned categories (that are salient in Norwegian society) have evaluative and descriptive implications regarding Turkish-Norwegian cooperation? ${ }^{38}$ The category most likely to be used is the one that at the time of a decision is most "accessible" and, further, the one that best fits the situation at hand. ${ }^{39}$ In other words, what are the connotations being evoked when Norwegians talk about Turkey and Turks? ? $^{40}$

One respondent stressed that a future obstacle to cooperation between Norway and Turkey could be the development of Turkophobia in Norwegian society. According to this opinionmaker, this situation could follow if a more general development of Islamophobia occurs as a result of the Oslo/Utøya tragedy. This point of view is supported by a 2012 survey by the Center for Studies of Holocaust and Religious Minorities in Norway. ${ }^{41}$

Breivik's horrifying attacks revealed a new side of Norway. During Breivik's trial, Professor Lars Gule, who has been following Norwegian right-wing extremist discussion groups on the Internet for years, estimated during his testimony that Breivik has between 12,000 and 15,000 sympathizers in Norway. ${ }^{42}$ Central to Breivik's ideology, which provided the basis for his actions, is the "two-faced" enemy image, consistent with that of the counter-

\footnotetext{
${ }^{36}$ Lerna K. Yanik, "The Metamorphosis of 'Metaphors of Vision': 'Bridging' Turkey's Location, Role and Identity after the End of the Cold War," Geopolitics 14 (2009): 531-549.

37 Henri Tajfel, "The Anchoring Effects of Value in a Scale of Judgments," British Journal of Psychology 50 (1959): $294-304$.

38 See Jason P. Mitchell, Brian A. Nosek, and Mahzarin R. Banaji, “Contextual Variations in Implicit Evaluation,” Journal of Experimental Psychology 132 (2003): 455-469.

39 Jerome S. Bruner, “On Perceptual Readiness,” Psychological Review 64 (1957): 123-151.

40 Connotations in this case are those meanings evoked in the meeting between the sign/category and the cultural conditions and values of the audience.

41 These results will be discussed below.

42 There are, however, few people who openly support Breivik's actions.
} 
jihadist movement. ${ }^{43}$ This image is composed of internal enemies and external enemies; the former include left-wing/Marxist/internationalists/multicultural elites within academia, politics, and the media and the latter include Islam and Muslims.

Central to this enemy image of Muslims are the following beliefs: (1) Islam is not only a religion, but it is also an ideology of hate; (2) there is no leeway for reform or moderation within Islam and thus there is no such thing as a moderate Muslim. All Muslims are consequently extremists; (3) Islam has an extraordinarily ability to homogenize its followers; (4) Islam and Muslims are in the process of taking over Europe; (5) The "Islam-problem" is a result of a deliberate policy by the left-wing, multicultural elites in Europe. ${ }^{44}$

The respondent noted above argued that if cooperation goes well between the two countries, the Norwegian public most likely would emphasize the indisputable European traits of Turkey, but in the case of conflict, Norwegians might quickly change to a more negative image of Turkey, where the key variable would be Turkey's Islamic character.

According to Samuel L. Gaertner, when two groups engage in a positively experienced cooperative task, a re-categorization process takes place..$^{45}$ The groups search for a common identity and create a "we" super-ordinate group identity. In the case of Norway and Turkey, this common ground would most likely be the "Europe" to which both countries belong. In other words, if there are positive sentiments in Norwegian society regarding cooperation, Turkey would be placed in the "Europa" category. Norway's common Europeanism will be the defining characteristic of this category. This super-ordinate in-group categorization also leads to the tendency to see the other member's unique features, which again gives members greater leeway within established norms ${ }^{46}$ Moreover, research has shown that more sharedcategory memberships translate into more positive evaluations. ${ }^{47}$

On the other hand, should cooperation create negative feelings between the two countries, the result might be an increasing designation of Turkey into the "Islam" category. Within the West, terrorism in the name of Islam has added very negative connotations to the concept of Islam. One consequence of the categorization processes described above is the fact that we are constantly reminded about the negative aspects of Islam. In the case of Turkey, the tendency might be to categorize it as "Islamic," ignoring the all the other characteristics that make it far more complex, such as the fact that Turkey has very strong secular traditions along with its Islamic religion. This aspect of Turkey makes it very different from other countries in the Islamic world. Furthermore, differences between human beings and groups in Turkey will be lost in this process of stereotyping. Turks will be made to look alike and be viewed as being different from Norwegians. In other words, what happens is a leveling of distinctions within the category "Islamic." If this type of thinking gains ground in a country like Norway, it could be increasingly difficult to maintain cooperation with Turkey. The inclination will be to look at Turkey through the lenses of identifying differences, instead of looking for common ground.

43 Siri M. Neset, Daniel Heradstveit, and G. Matthew Bonham, "The Lone Wolf behind the Norwegian Tragedy: The Ideological Foundations of Anders Behring Breivik" (paper presented at the 35th Annual Scientific Meeting of the International Society of Political Psychology, Chicago, Illinois, July 6-9, 2012).

${ }_{44}$ See Bjørn Stærk, "En Nettreise gjennom Islam-kritikkens Tiår,” Samtiden 4 (2011): 32-49.

45 Samuel L. Gaertner et al., "The Common In-Group Identity Model: Recategorization and the Reduction of Intergroup Bias," European Review of Social Psychology 4 (1993): 1-26.

46 Musafer Sherif and Carolyn W. Sherif, Social Psychology (New York: Harper and Row, 1996).

47 Michael J. Migdal, Miles Hewstone, and Brian Mullen, "The Effects of Crossed Categorization in Intergroup Evaluations: 
These negative attributions to Islam can collectively be labeled as "Islamophobia," and its rise stems from a mixture of radical Islam creeping out after 9/11, the war against terror, and bombings in Europe, as well as European disputes over headscarves, building mosques, and reactions to the caricature drawings. Islamophobia (and other such constructs) emerges from simplistic interpretative frameworks like "good versus evil" or "Christianity versus Islam". Islamophobia itself is further triggered by the stance of a radical minority on the peaceful ground of the majority of religious groups. Too often, this leads to generalizations that have become common in Europe. According to Gökhan Saz, Turkophobia can be viewed as the extension of this stylized Islamophobia. ${ }^{48}$ Islamophobia rests on cultural misunderstandings and miscommunication. This problem is reinforced by the lack of political vision, and the virtually non-existing policies of integration for the Turkish population in Europe.

Although Saz refers to the EU countries, Norway also harbors negative connotations of Islam, both in its official discourse and in Norwegian society in general. The Progress Party, one of Norway's largest political parties, has a clear anti-immigrant profile, and it has been known to reproduce stereotypes about Islam..$^{49}$ The Council of Europe's European Commission against Racism and Intolerance (ECRI) reveals in its latest report that "during the run-up to the September 2005 general elections, the Progress Party disseminated a brochure establishing, through text and images, very clear links between serious security issues and persons of foreign origin". ${ }^{50}$ A survey from 2012 by the Center for Studies of Holocaust and Religious Minorities indicates that there is a substantial presence of antiMuslim sentiments in the Norwegian population. ${ }^{51}$ The results reveal that $10 \%$ would strongly dislike having a Muslim as one of their neighbors, and $11 \%$ would strongly dislike having a Muslim introduced into a circle of friends. Moreover, $38 \%$ would strongly dislike having a Muslim marry into the family. Also, ECRI finds that more generally, "the expression of anti-immigrant views in political and public debate has become more common in Norway in recent years. In particular...[there has been] a rise in the association of Muslims, on the one hand, and terrorism and violence on the other, as well as generalizations and stereotypes concerning persons of Muslim background." 52

We have not found specific reference to Turkophobia in Norwegian discourse, and can only speculate about why. It seems that Norwegians do not link Turks and Turkey with Muslims and Islam. This cannot be explained by geography alone; more important are the cultural and ideological factors upon which Turkey's republic was built. Its founder, Ataturk, was inspired first and foremost by the French Revolution, which had a counter-ideology to the Ottoman Empire. By moving Turkey's capital from Istanbul to Ankara in 1923, Ataturk made it symbolically clear from the outset that the new republic had nothing in common

\footnotetext{
48 Gökhan Saz, "Turkophobia and Rising Islamophobia in Europe: A Quantification for the Negative Spillovers on the EU Membership Quest of Turkey," Journal of Social Science 19 (2011): 479-491.

49 Kent Andersen and Christian Tybring Gjedde, "Drøm fra Disneyland," Aftenposten, August 27, 2010, accessed December 18, 2012, http://www.aftenposten.no/meninger/kronikker/article3783373.ece.

Also, Kirsti Haga Honningsøy, "Grotesk utsagn fra Hagen," NRK, August 14, 2011, accessed December 18, 2012, http:// www.nrk.no/nyheter/norge/1.7749407. Also, Sindre Bangstad, "Norway: Terror and Islamophobia in the Mirror," Open Democracy, August 27, 2011, accessed December 18, 2012, http://www.opendemocracy.net/sindre-bangstad/norway-terror-and-islamophobiain-mirror.

50 Council of Europe: European Commission against Racism and Intolerance, "ECRI Report on Norway (Fourth Monitoring Cycle)," February 4, 2009: 27, accessed December 18, 2012, http://www.unhcr.org/refworld/docid/49e8891af.html.

51 Christhard Hoffmann, Øivind Kopperud and Vibeke Moe, "Antisemittisme i Norge? Den Norske Befolkningens Holdninger til Jøder og andre Minoriteter, " The Center for Studies of Holocaust and Religious Minorities, May 2012, accessed December 18, 2012, http://www.hlsenteret.no/publikasjoner/HL_Rapport_2012_web.pdf. English summary on page 8.

52 ECRI, 27
} 
with the Ottoman Empire. He wanted to create a modern republic built on modern Western principles. Ataturk introduced secularism as the main creed of the new republic and dealt with religion in a heavy-handed manner. Religious utterances in public spaces were forbidden, as was wearing headscarves. The implications of Ataturk's ideology also put relative distance between Turkey's Arab neighbors and Europe's profits, which explains Turkey's consistent attachment to Europe since then. Its pending application to become a member of the EU is the most visible sign of this political orientation in recent years.

In addition to Turkey's historical connection to Europe and state secularism, we find that in Norwegian discourse the Kurdish people and the Turkish people are clearly recognized as separate ethnic groups. When speaking with Norwegians about Turkey, what first comes to mind is tourism, i.e., the city of Istanbul and Turkey's vacation resorts in the south.

Despite our respondents welcoming closer cooperation between Turkey and Norway, the rise of Islamophobia (and possibly its corollary Turkophobia) in Norwegian society cannot be ignored. In our opinion, this construct is not likely to become widespread, but as history shows, more often than not, the unlikely happens. For this reason, we find it highly relevant to include this area in our research.

\section{Conclusion}

Our respondents agreed that Turkey and Norway have a unique opportunity after the Arab Spring to benefit from closer cooperation on issues of democracy and peace. They maintain that the two countries can complement each other; Norway's soft power and the Turkish Model together are bound to create a positive interaction effect on mutual efforts to promote democratic developments in the Arab Middle East.

\section{Bibliography}

Aberbach, Joel D., and Bert A. Rockman. “Conducting and Coding Elite Interviews.” Political Science and Politics 35 (2002): 673-676.

Andersen, Kent, and Christian Tybring Gjedde. "Drøm fra Disneyland.” Aftenposten, August 27, 2010. Accessed December 18, 2012. http://www.aftenposten.no/meninger/kronikker/article3783373.ece.

Bangstad, Sindre. "Norway: Terror and Islamophobia in the Mirror." Open Democracy, August 27, 2011. Accessed December 18, 2012. http://www.opendemocracy.net/sindre-bangstad/norway-terror-and-islamophobia-inmirror.

Berry, Jeffery M. "Validity and Reliability Issues in Elite Interviewing." Political Science and Politics 35 (2002): 679-682.

Bruner, Jerome S. “On Perceptual Readiness.” Psychological Review 64 (1957): 123-151.

"ECRI Report on Norway (Fourth Monitoring Cycle)," Council of Europe: European Commission against Racism and Intolerance (ECRI), February 4, 2009: 27. Accessed December 18, 2012, http://www.unhcr.org/refworld/ docid/49e8891af.html.

Ferraris, Maurizio. History of Hermeneutics. New York: Humanities Press, 1996.

Fuller, Graham E. “Turkey’s Strategic Model: Myths and Realities.” The Washington Quarterly 27 (2004): 51-64.

Gadamer, Hans Georg. "Interview: Writing and the Living Voice.” In Hans-Georg Gadamer on Education, Poetry and History, edited by Dieter Misgeld and Graeme Nicholson, 63-71. New York: State University of New York Press, 1992.

Gaertner, Samuel L., John F. Dovidio, Phyllis A. Anastasio, Betty A. Bachman, and Mary C. Rust. "The Common Ingroup Identity Model: Recategorization and the Reduction of Intergroup Bias.” European Review of Social 
George, Alexander L., and Andrew Bennett. Case Studies and Theory Development in the Social Sciences. Cambridge: MIT Press, 2005.

Heradstveit, Daniel. The Arab-Israeli Conflict: Psychological Obstacles to Peace. Oslo: Universitetsforlaget, 1979; New York: Columbia University Press, 1981.

Hoffmann, Christhard, and Øivind Kopperud, and Vibeke Moe. "Antisemittisme i Norge? Den Norske Befolkningens Holdninger til Jøder og andre Minoriteter." Center for Studies of Holocaust and Religious Minorities, May 2012. Accessed December 18, 2012. http://www.hlsenteret.no/publikasjoner/HL_ Rapport_2012_web.pdf.

Honningsøy, Kirsti Haga. “Grotesk utsagn fra Hagen.” NRK, August 14, 2011. Accessed December 18, 2012. http://www.nrk.no/nyheter/norge/1.7749407.

Jervis, Robert. Perception and Misperception in International Politics. Princeton: Princeton University Press, 1976.

Kaddorah, Emad. "The Turkish Model: Acceptability and Apprehension.” Insight Turkey 12 (2010): 113-129.

Lunde, Leiv, Henrik Thune, Eiler Fleischer, Leo Grunfeld, and Ole Jacob Sending. Norske Interesser: Utenrikspolitikk for en Globalisert Verden. Oslo: Cappelen Damm, 2008.

"Magt og Demokrati. Magt og Demokratiutredniningens Sluttrapport.” Norwegian Official Reports. NOU 2003: 19. Oslo: Statens Forvaltningsteneste, 2003.

McClory, Jonathan. “The New Persuaders II: A 2011 Global Ranking of Soft Power.” The Institute for Government, December 1, 2011. Accessed December 18, 2012. http://www.instituteforgovernment.org.uk/ publications/new-persuaders-ii.

Migdal, Michael J., Miles Hewstone, and Brian Mullen. "The Effects of Crossed Categorization in Intergroup Evaluations: A meta-analysis.” British Journal of Social Psychology 37 (1998): 303-324.

Mitchell, Jason P., Brian A. Nosek, and Mahzarin R. Banaji. "Contextual Variations in Implicit Evaluation." Journal of Experimental Psychology 132 (2003): 455-469.

Muasher, Marwan, Thomas de Waal, Thomas Carothers and Sinan Ülgen. "Can the Turkish Model Gain Traction in the New Middle East?” Carnegie Endowment for International Peace, December 19, 2011. Accessed November 2, 2012. http://carnegieendowment.org/2011/12/19/can-turkish-model-gain-traction-in-newmiddle-east.

Neset, Siri M., Daniel Heradstveit, and G. Matthew Bonham. "The Lone Wolf behind the Norwegian Tragedy: The Ideological Foundations of Anders Behring Breivik." Paper presented at the 35th Annual Scientific Meeting of the International Society of Political Psychology, Chicago, Illinois, July 6-9, 2012.

"Norge i fredens tjeneste: Norske bidrag til fred og forsoning." Norwegian Ministry of Foreign Affairs, July 7, 2000. Accessed December 26, 2012. http://www.regjeringen.no/en/dep/ud/documents/Reports-programmesof-action-and-plans/Reports/2000/fredenstjeneste.html?id=467585.

Nye, Joseph S. Soft Power: The Means to Success in World Politics. New York: Public Affairs, 2004.

Oğuzlu, Tarık. "Is the 'Turkey As a Model' Idea Turning into Reality from Perception?” ORSAM, December 5, 2011. Accessed February 11, 2013. http://www.orsam.org.tr/en/showArticle.aspx?ID=951.

Onar, Nora Fisher. “Turkey Inc.: Rethinking the Model's Regional Role.” Carnegie Endowment for International Peace, March 29, 21012. Accessed February 10, 2013, http://carnegieendowment.org/sada/2012/03/29/turkeyinc.-rethinking-turkey-s-regional-role/a5k9.

"Policy of Zero Problems with our Neighbors." Republic of Turkey, Ministry of Foreign Affairs, 2011. Accessed November 10, 2012. http://www.mfa.gov.tr/policy-of-zero-problems-with-our-neighbors.en.mfa.

"Press release: Increased Cooperation between Norway and Turkey." Norway, The Office of the Prime Minister, January 10, 2012. Accessed November 6, 2012. http:/www.regjeringen.no/en/dep/smk/press-center/Pressreleases/2012/increased-cooperation-between-norway-and.html?id=668571.

Saz, Gökhan. "Turkophobia and Rising Islamophobia in Europe: A Quantification for the Negative Spillovers on the EU Membership Quest of Turkey.” Journal of Social Science 19 (2011): 479-491. 
Sherif, Musafer, and Carolyn W. Sherif. Social Psychology. New York: Harper \& Row, 1969.

Skånland, Øystein Haga. "Norway is a Peace Nation: a Discourse Analytic Reading of the Norwegian Peace Engagement." Cooperation and Conflict 45 (2010): 35-54.

Stærk, Bjørn. “En Nettreise gjennom Islam-kritikkens Tiår.” Samtiden 4 (2011): 32-49.

Støre, Jonas G. ”Utenrikspolitikk i Forandringens tid.” Samtiden 4 (2010): 4-19.

Tajfel, Henri. "The Anchoring Effects of Value in a Scale of Judgments." British Journal of Psychology 50 (1959): 294-304.

Tansey, Oisin. "Process Tracing and Elite Interviewing: a Case for Non-probability Sampling." Political Science and Politics 40 (2007): 765-772.

“Turkey from Ataturk to Erdogan." Asharq al-Awsat, November 9, 2007. Accessed February 9, 2013, http://www. aawsat.net/2007/11/article55260861.

“Turkish Model has Shortcomings.” Oxford Analytica, February 21, 2011. Accessed February 05, 2013. http:// www.relooney.info/0_NS4053_1608.pdf.

Yanik, Lerna K. “The Metamorphosis of 'Metaphors of Vision': 'Bridging' Turkey's Location Role and Identity after the End of the Cold War." Geopolitics 14 (2009): 531-549. 